\section{Scientific journal}

PHYSICAL AND MATHEMATICAL EDUCATION

Has been issued since 2013.

Науковий журнал

ФІЗИКО-МАТЕМАТИЧНА ОСВІТА

Видається з 2013.
ISSN 2413-158X (online)

ISSN 2413-1571 (print)

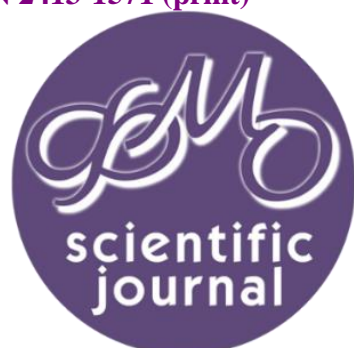

Розуменко А.О., Розуменко А.М. Моніторинг знань як інструмент забезпечення якісної математичної підготовки студентів. Фізико-математична освіта. 2021. Випуск 3(29). С. 105-111.

Rozumenko A.O., Rozumenko A.M. Knowledge monitoring as a tool for providing quality mathematical training of students. Physical and Mathematical Education. 2021. Issue 3(29). P. 105-111.

DOI 10.31110/2413-1571-2021-029-3-016

Удк 373.5.016:519.2

А.О. Розуменко

Комунальний заклад Сумської обласної ради «Сумська обласна гімназія-інтернат для талановитих та творчо обдарованих дітей», Україна

angelarozumenko@ukr.net

ORCID: 0000-0002-4759-3320

А.М. Розуменко

Сумський національний аграрний університет, Україна a.rozumenko@snau.edu.ua

ORCID: 0000-0002-3069-9313

\title{
МОНІТОРИНГ ЗНАНЬ ЯК ІНСТРУМЕНТ ЗАБЕЗПЕЧЕННЯ ЯКІСНОÏ МАТЕМАТИЧНОЇ ПІДГОТОВКИ СТУДЕНТІВ
}

\section{АНОТАЦІЯ}

Формулювання проблеми. В статті розглянуто проблему зниження якості математичної підготовки студентів різних спеціальностей.

Матеріали і методи. У ході підготовки статті були використані такі методи дослідження: порівняльний аналіз теоретичних положень, розкритих у науковій та навчально-методичній літературі; спостереження за математичною підготовкою майбутніх фахівців різних напрямів; бесіди із студентами; узагальнення педагогічного досвіду з викладання математичних дисциплін, анкетування (239 респондентів) та статистичні методи обробки експериментальний даних (метод статистичних гіпотез).

Результати. На основі аналізу моніторингових досліджень різних рівнів зроблено висновок про те, що якість математичної підготовки майбутніх фахівців має тенденцію зниження незалежно від напряму підготовки. Наведено результати експериментального регіонального дослідження, що підтверджують цей висновок.

Обгрунтовано необхідність проведення моніторингу математичних знань як одного із інструментів забезпечення більш якісної математичної підготовки студентів.

Запропоновано методичні рекомендації щодо підвищення якості математичної підготовки студентів першого року навчання різних напрямів підготовки.

Висновки. Підтверджено, що система моніторингу має бути комплексною та проводитися на всіх рівнях управління освітою як запорука валідності, надійності, економічності, інтегрованості та практичності. Моніторинг навчальних досягнень студентів є інструментом, який дозволяє забезпечити якісну математичну підготовку майбутніх фахівців. Здійснення експериментального дослідження дало змогу виявити відсутність узгодженості результату зно, шкільного середнього балу з математики та результатів іспиту з математики, що складали студенти першого року різних університетів. Для уникнення прогалин та корекції знань першокурсників доцільно організувати протягом першого семестру повторювальний курс икільної математики, завдання якого є узагальнення і систематизація основних фактів арифметики, геометрії, алгебри та початків аналізу. Це дозволить покращити якість математичної підготовки студентів закладів вищої освіти.

кЛЮчОвІ СлОвА: математична підготовка, моніторинг, студент, якість освіти.

\section{ВСТУП}

Постановка проблеми. Сучасний етап розвитку українського суспільства потребує фахівців високого рівня підготовки. Україна, як і інші індустріальні держави, має технічну інфраструктуру, яку необхідно постійно підтримувати, розвивати та оновлювати. Недостатня підготовка кадрів може призвести до занепаду виробництва, руйнування інфраструктури і до зупинки цивілізаційного розвитку, що буде мати численні негативні наслідки для українського народу. У підготовці майбутніх фахівців, зокрема інженерно - технічних спеціальностей, які забезпечують життєздатність технічної 
інфраструктури держави, особливе місце займає математична підготовка. Останнім часом спостерігається зниження якості математичної підготовки фахівців різних напрямків підготовки. Проблема важлива і багатоаспектна. Розуміння актуальності цієї проблеми на рівні держави призвело до того, що навчальний 2020-2021 рік в Україні було проголошено роком математичної освіти (Про оголошення, 2020).

Актуальність дослідження. Докорінним чином змінити негативну тенденцію, яка спостерігається в математичній освіті, може реалізація системних реформ, для успішного здійснення яких необхідні чіткі рекомендації вчених-методистів, психологів, педагогів. На нашу думку, однією з умов забезпечення якісної математичної підготовки студентів вищих закладів освіти $€$ різнорівневий моніторинг їх навчальних досягнень.

Мета статті полягає в аналізі моніторингових досліджень різних рівнів щодо математичної підготовки майбутніх фахівців різних спеціальностей, обґрунтуванні необхідності проведення моніторингу математичних знань студентів і розробці методичних рекомендацій щодо підвищення якості їх математичної підготовки.

\section{МЕТОДИ ДОСЛІДЖЕННЯ}

У ході підготовки статті були використані такі методи дослідження: порівняльний аналіз теоретичних положень, розкритих у науковій та навчально-методичній літературі; спостереження за математичною підготовкою майбутніх фахівців різних напрямів; бесіди із студентами; узагальнення педагогічного досвіду з викладання математичних дисциплін, анкетування (239 респондентів) та статистичні методи обробки експериментальний даних (метод статистичних гіпотез).

\section{РЕЗУЛЬТАТИ ДОСЛІДЖЕННЯ ТА ОБГОВОРЕННЯ}

Реформи в освіті України спрямовані на підвищення їі якості. У Законі України «Про освіту» (2017) поняття «якість освіти» визначено як відповідність результатів навчання вимогам, встановленим законодавством, відповідним стандартом освіти та/або договором про надання освітніх послуг» (Закон України «Про освіту», 2017).

Міністерство освіти і науки України трактує поняття якості освіти як:

1) комплекс характеристик освітнього процесу, що визначають послідовне та практично ефективне формування компетентності та професійної свідомості;

2) певний рівень знань і вмінь, розумового, фізичного і морального розвитку, якого досягли випускники освітнього закладу відповідно до запланованих цілей навчання та виховання (Якість освіти, 2021).

Відповідно до такого підходу, в Україні формами оцінювання якості освіти в повній загальній середній освіті $\epsilon$ зовнішнє незалежне оцінювання (ЗНО), державна підсумкова атестація (ДПА) та Програма міжнародного оцінювання (PISA). Всі зазначені форми оцінювання $€$ моніторинговими дослідженнями різного рівня.

\section{Моніторинг в освіті України}

Термін «monitoring» означає постійний контроль, цей термін утворений від латинського «monitor» - той, що контролює. Поняття «моніторинг» прийшло у педагогіку з екології та соціології. В екології моніторинг - це спостереження за довкіллям, оцінка й прогноз його стану у зв'язку з господарською діяльністю людини і з метою попередження небажаних відхилень за важливішими параметрами. У соціології моніторинг розглядається як збір інформації для вивчення громадської думки щодо якогось питання. Аналіз наукової літератури свідчить, що поняття «моніторинг» в освіті почали використовувати у 60-х роках XX століття. Одне з перших його трактувань, як технології постійного спостереження конкретного явища, його оцінки і прогнозування розвитку, було опубліковано в 1977 році у Міжнародній енциклопедії освіти.

Поняття «моніторинг» можна трактувати як систематичне спостереження за будь-яким процесом для встановлення відповідності (чи невідповідності) результатів цього процесу початковим припущенням; комплекс заходів, спрямований на отримання повної, орієнтованої на предметну галузь інформації про функціонування складної системи для управління нею.

Освітній моніторинг має свою специфіку. Моніторинг в освіті розглядається як система збору, обробки, збереження та розповсюдження інформації про освітню систему або окремі ї̈ компоненти. Це система інформаційного забезпечення управління, яка дає змогу зробити висновки про стан об'єкта у будь-який момент і дати прогноз його розвитку.

Науковці вважають, що об'єктами моніторингу в освіті можуть бути:

- система освіти (загальна середня, професійна, вища, національна або загальнодержавна, регіональна, муніципальна, інституціональна або локальна);

- результати навчальної діяльності;

- характеристики учасників освітнього процесу (стан здоров'я, соціальний захист, умови життя й навчання, готовність до здійснення певної діяльності, задоволеність освітніми послугами тощо);

- відносини споживачів освітніх послуг з освітнім середовищем (оточуючим соціумом);

- процеси функціонування і розвитку освітніх систем та управління ними;

- компоненти освітнього процесу:

- умови і засоби реалізації освітнього процесу (матеріально-технічні, санітарно-гігієнічні, нормативно-правові, кадрові, фінансові, навчально-методичні умови тощо);

- організація освітнього процесу (мережі освітніх установ, контингент та його диференціація за різними ознаками, режим роботи, розклад навчальних занять тощо);

- наслідки освітнього процесу (результати запровадження освітніх реформ, змін навчальних програм і освітніх стандартів тощо)( Ляшенко\& Лукіна, 2011).

Системи моніторингу якості освіти можуть бути реалізовані на різних рівнях управління освітніми процесами, а саме локальному, регіональному, національному та міжнародному. Розглянемо кожний рівень більш докладно. 
Локальний моніторинг - це моніторинг на рівні окремого навчального закладу (школи, коледжу, університету) Локальний моніторинг здійснюється суб'єктами самого освітнього закладу. Його метою є отримання інформації про реальний стан справ в освітній установі, виявлення причин недоліків роботи для виправлення ситуації, надання методичної і практичної допомоги вчителям та викладачам.

У результаті аналізу наукових джерел ми прийшли до висновку, що для ефективного моніторингу на локальному рівні необхідно створити інформаційну систему, яка повинна постійно поповнюватися завдяки безперервності відстеження певного об'єкта управління за виділеними параметрами та критеріями їх оцінювання, на підставі проведення поточного контролю, оцінки та корекції стану об'єкта, з метою прийняття оперативного управлінського рішення щодо прогнозування напрямків подальшого розвитку керованого об'єкта.

Регіональний моніторинг $є$ важливим процесом, оскільки даний вид моніторингу $є$ основою для створення інформаційно-аналітичної бази регіональної і національної політики в галузі модернізації освіти. Проведенням моніторингових досліджень у регіонах України займаються спеціальні установи, які називаються інститутами післядипломної педагогічної освіти.

Проведений аналіз дав підстави для висновку, що в Україні відсутній систематичний моніторинг освітніх результатів і соціальних ефектів освітньої системи на регіональному рівні. Окремі моніторингові заходи, що здійснюються, орієнтовані в основному на процеси, що відбуваються в системі, а не на оцінювання результатів їі функціонування. Органи управління освітою регіонального рівня, які організовують і проводять дослідження, недостатньо підготовлені щодо оцінювання результатів і соціальних ефектів освітньої діяльності; щодо визначення сильних і слабких сторін роботи конкретних навчальних закладів у контексті забезпечення якості.

У різних регіонах України впродовж багатьох років здійснюються ініціативні моніторингові дослідження з різних проблем освітньої практики (у більшості випадків оцінюються навчальні досягнення учнів різних вікових груп з окремих предметів). Такі обстеження також можуть бути корисними для здійснення системного моніторингу якості освіти, якщо їх упорядкувати, виконувати за єдиною методологією і координувати їх проведення на загальнодержавному рівні.

Національні системи моніторингу якості освіти мають відповідне інституційне забезпечення. Як правило, воно складається з інституції, що здійснює збирання, збереження й аналіз даних про систему освіти та є утримувачем інформаційної системи управління освітою; інституцій, які проводять моніторингові дослідження якості освіти, зовнішні іспити тощо.

Одним із нововведень, що вкоренилося в українській системі освіти, стало проведення зовнішнього незалежного оцінювання.

Зовнішнє незалежне оцінювання (ЗНО) - це комплекс організаційних процедур (передусім - тестування), спрямований на визначення рівня навчальних досягнень випускників середніх навчальних закладів при їхньому вступі до вищих навчальних закладів. Мета зовнішнього незалежного оцінювання: підвищення рівня освіти населення України та забезпечення реалізації конституційних прав громадян на рівний доступ до якісної освіти, здійснення контролю за дотриманням Державного стандарту базової і повної середньої освіти й аналізу стану системи освіти, прогнозування їі розвитку.

У контексті нашого дослідження було зроблено аналіз результатів ЗНО з математики. Одним з показників рівня математичної підготовки учнів випускних класів $є$ відсоток учнів, що взагалі не склали тест. За останні три роки цей показник поступово погіршувався: у 2016 році він становив 12,7\%, у 2017 збільшився до 14\% , а в 2018 був зафіксований максимальний показник - 15\% (Офіційні звіти, 2021). Ці факти підтверджують актуальність проблеми зниження якості математичної підготовки випускників шкіл.

Міжнародні дослідження в освіті націлені на порівняння результатів функціонування національних систем освіти, на виявлення стану грамотності і освіти в різних країнах. Піввіковий досвід проведення подібних досліджень показує, що міжнародні порівняльні дослідження вносять нові знання, нову методологію, нове розуміння дослідницької діяльності в сучасному світі, відкривають нові перспективи розвитку порівняльного освіти.

В міжнародній педагогіці використовують різні засоби вимірювання навчальних досягнень учнів (Байназарова,2009) в межах проведення різних моніторингових програм (таблиця 1).

Зауважимо, що у 2007 р. та 2011 р. Україна брала участь у програмі TIMSS, однак із різних причин в подальшому ця практика припинилася. Серед міжнародних досліджень якості освіти наша країна бере участь лише в PISA (iз 2016 р.). Одним із завдань даної моніторингової програми є дослідження рівня сформованості математичної грамотності 15-річних підлітків.

Велику дискусію в українському суспільстві викликали результати українських учнів, що брали участь в міжнародній програмі PISA в 2018 році. Як зазначено в національному звіті (Національний звіт, 2018), математична грамотність учня / студента визначається як його здатність формулювати, застосовувати й інтерпретувати математику в різноманітних контекстах. Це включає математичні міркування й застосування математичних понять, процедур, фактів та інструментів для опису, пояснення й прогнозування явищ. Грамотність у галузі математики допомагає зрозуміти роль математики у світі, робити аргументовані висновки й приймати рішення, необхідні людям як творчим, активним і свідомим громадянам. У PISA базовий рівень сформованості тієї чи тієї грамотності визначається як рівень мінімального оволодіння змістом тієї чи тієї предметної галузі й мінімальної сформованості умінь самостійно мислити. На жаль, навіть базового рівня сформованості математичної грамотності не досягли 36 \% українських підлітків. Цей показник $є$ гіршим за середнє значення по країнах ОЕСР, де базового рівня сформованості математичної грамотності не досягли 23,9 \% (Байназарова,2009).

Аналіз цих даних підтверджує висновок про недостатню математичну підготовку учнів українських шкіл. 
Засоби вимірювання навчальних досягнень учнів за різними міжнародними програмами моніторингу

\begin{tabular}{|c|c|}
\hline International monitoring program & Content \\
\hline $\begin{array}{l}\text { Programmer for International Student Assessment } \\
\text { (PISA) }\end{array}$ & $\begin{array}{l}\text { assessment of students' knowledge and skills in the areas of «reading } \\
\text { literacy», «mathematical literacy», «natural science literacy» }\end{array}$ \\
\hline $\begin{array}{l}\text { Trends in International Mathematics and Science } \\
\text { Study (TIMSS) }\end{array}$ & $\begin{array}{l}\text { international study of the quality of mathematics and science } \\
\text { education }\end{array}$ \\
\hline $\begin{array}{l}\text { Progress in International Reading Literacy Study } \\
\text { (PIRLS) }\end{array}$ & $\begin{array}{l}\text { international project "Study of reading quality and text } \\
\text { comprehension" }\end{array}$ \\
\hline Civic Education Study (CIVIC) & $\begin{array}{l}\text { comparative assessment of civic education of secondary and primary } \\
\text { school graduates }\end{array}$ \\
\hline $\begin{array}{l}\text { Second Information Technology in Education Study } \\
\text { (SITES) }\end{array}$ & $\begin{array}{l}\text { comparative study of information and communication technologies in } \\
\text { education }\end{array}$ \\
\hline First International Mathematics Study (FIMS) & assessment of success in mathematics in primary and secondary school \\
\hline Second International Mathematics Study (SIMS) & $\begin{array}{l}\text { study of students' success in mastering mathematics, natural sciences, } \\
\text { English and French as foreign languages, as well as the study of the } \\
\text { learning environment within one class }\end{array}$ \\
\hline Language Education Study (LES) & devoted to the study of the state of teaching foreign languages \\
\hline Computers in Education Study (COMPED) & study of the use of computers in education \\
\hline Monitoring in Eastern Europe & $\begin{array}{l}\text { project, the purpose of which was to analyze the social living conditions } \\
\text { of children, their families and public policy of post-socialist countries }\end{array}$ \\
\hline $\begin{array}{l}\text { International Comparative Study on Mathematics } \\
\text { Teacher Training (ICSMTT) }\end{array}$ & international comparative study of mathematics teacher training \\
\hline
\end{tabular}

\section{Результати експериментального дослідження}

Викладачі вищих навчальних закладів також відмічають тенденції зниження рівня математичної підготовки студентів. Досвід роботи свідчить про те, що випускники шкіл, які за результатами зовнішнього незалежного оцінювання мають навіть "достатні» бали для вступу на спеціальності, де необхідним є сертифікат з математики, досить часто не можуть засвоїти навчальний матеріал математичних дисциплін, які починають вивчати в університеті. Виникає питання: $у$ чому причини проблеми? Можливо, що прогалини в знаннях, невміння виділяти головне, міркувати, робити висновки і взагалі вчитися самостійно є наслідком того, що школа орієнтує учня на «результат знО». Так, це важливо. Але ж відпрацювання певних тем, типів завдань, не забезпечує якісну математичну підготовку учня.

На нашу думку, існує певна невідповідність оцінювання математичних знань учня-випускника та студентапершокурсника. 3 метою підтвердження чи спростування даної тези нами було проведено експериментальне дослідження, теоретичною основою якого є система моніторингу якості освіти.

3 метою дослідження питання відповідності рівня знань 3 математики учнів-випускників та студентівпершокурсників, що вивчають математичні дисципліни, нами було проведено анкетування. В анкетуванні брали участь 239 студентів першого курсу різних спеціальностей різних вищих навчальних закладів міста Суми (Україна). Кількісний склад учасників експерименту подано в таблиці 2.

Табличя 2

Кількісний склад учасників експерименту

\begin{tabular}{|c|c|}
\hline ВНз & Кількість студентів \\
\hline $\begin{array}{c}\text { Сумський національний аграрний університет } \\
\text { (інженерні спеціальності) }\end{array}$ & 139 \\
\hline $\begin{array}{c}\text { Сумський державний університет } \\
\text { (інженерні спеціальності) }\end{array}$ & 45 \\
\hline $\begin{array}{c}\text { Сумський державний педагогічнй університет ім. А. С. Макаренка } \\
\text { (фізико-математичний факультет) }\end{array}$ & 55 \\
\hline
\end{tabular}

Всі студенти, що брали участь в експериментальному дослідження мали сертифікат зовнішнього незалежного оцінювання (3НО) з математики (не нижче 140 балів з 200 можливих) та продовжували вивчати математичні дисципліни у вищому навчальному закладі.

Результати анкетування ми опрацьовували в три етапи, з використанням відповідних методів статистичної обробки даних:

1. Порівнювали шкільний середній бал (за оцінками в атестаті про середню освіту) з математики та результат зовнішнього незалежного оцінювання кожного респондента.

2. Порівнювали результат 3 НО з результатами іспиту з математики, що студенти-першокурсники складали під час першої сесії у вищих навчальних закладах.

3. Порівнювали результат шкільного середнього балу з математики та результат іспиту з математики, що студентипершокурсники складали під час першої сесії у вищих навчальних закладів.

При порівнянні результатів шкільного середнього балу з математики, балів зовнішнього незалежного оцінювання та результатів іспиту з математичних дисциплін, що студенти-першокурсники складали під час першої сесії у закладах вищої освіти, нами були виділені 3 рівні математичної підготовки студентів (таблиця 3). 
Рівні математичної підготовки за результатами моніторингу

\begin{tabular}{|c|c|c|c|}
\hline Рівень (ранг) & $\begin{array}{c}\text { Кількість балів за шкільним } \\
\text { атестатом } \\
\text { (максимально-12) }\end{array}$ & $\begin{array}{c}\text { Кількість балів за результатом } \\
\text { ЗнО } \\
\text { (максимальна кількість-200) }\end{array}$ & $\begin{array}{c}\text { Іспит з математичної } \\
\text { дисципліни } \\
\text { (максимальна кількість - 100) }\end{array}$ \\
\hline Середній & $4-6$ & $140-150$ & $60-74$ \\
\hline Достатній & $7-9$ & $151-183$ & $75-89$ \\
\hline Високий & $10-12$ & $183,5-200$ & $90-100$ \\
\hline
\end{tabular}

Розподіл учасників експерименту по рівнях математичної підготовки подано в таблиці 4.

Розподіл учасників експерименту за виділеними рівнями математичної підготовки

\begin{tabular}{|c|c|c|c|c|c|c|}
\hline Вівні & \multicolumn{2}{|c|}{ 3нО } & \multicolumn{2}{c|}{ Іспит } \\
\hline Середній & \multicolumn{2}{|c|}{ шкільний бал } & 38 & $27,6 \%$ & 66 & $54,4 \%$ \\
\hline Достатній & $15,9 \%$ & 162 & $59,8 \%$ & 143 & $39,7 \%$ & 95 \\
\hline Високий & $67,8 \%$ & 39 & $12,6 \%$ & 30 & $5,9 \%$ \\
\hline
\end{tabular}

3 метою встановлення однорідності результатів оцінювання математичних знань учнів і студентів ми використовували метод статистичних гіпотез, а саме метод перевірки статистичних гіпотез за критерієм $\mathcal{X}^{2}$.

Нульова гіпотеза полягала в тому, що характеристики двох вибірок за виділеними критеріями співпадають на рівні значущості $\alpha=0,05$.

Альтернативна гіпотеза полягала в тому, що характеристики цих вибірок за виділеними критеріями суттєво відрізняються на вибраному рівні значущості.

Гіпотези перевірялися за критерієм $\chi^{2}$. За результатами експерименту нами були обчислені емпіричні значення критерію за формулою:

$$
\chi_{\text {експ. }}^{2}=N \cdot M \cdot \sum_{i=1}^{L} \frac{\left(\frac{n_{i}}{N}-\frac{m_{i}}{M}\right)^{2}}{n_{i}+m_{i}}, \text { де }
$$

$L$ - кількість рангів (кількість виділених рівнів),

$N$ - кількість респондентів (осіб) експериментальної групи,

$M$ - кількість респондентів (осіб) контрольної групи,

$n_{i}$ - кількість респондентів експериментальної групи, що відповідають $i$ - му рангу,

$m_{i}$ - кількість респондентів контрольної групи, що відповідають $i$ - му рангу (Новиков, 2004).

Результати обчислень емпіричних значень критерію подано в таблиці 5.

Таблиця 5

Емпіричні значення критерію за вибірками

\begin{tabular}{|c|c|}
\hline Вибірки, що порівнювались & Емпіричне значення критерію $\chi^{2}{ }_{\text {експ. }}$ \\
\hline Шкільний бал і зНО & 9,9 \\
\hline ЗНО і результати іспиту & 36,4 \\
\hline Шкільний бал і результати іспиту & 79,6 \\
\hline
\end{tabular}

В нашому дослідженні $L=3$ (виділено три рівні математичних знань респондентів: середній, достатній і високий), тому критичне значення критерію $\chi^{2}{ }_{\text {кр. }}=5,99$ (для рівня значущості $\alpha=0,05$ ).

Всі емпіричні значення критерію за значенням більше критичного $\chi_{\text {кр. }}^{2}$. Отже, відповідно до правила перевірки статистичних гіпотез можна зробити висновок про те, що характеристики вибірок за виділеними критеріями суттєво відрізняються.

Наочно результати опрацювання першого етапу дослідження представлені на рисунку 1.

Наочно результати опрацювання другого етапу дослідження представлені на рисунку 2.

Наочно результати опрацювання третього етапу дослідження представлені на рисунку 3.

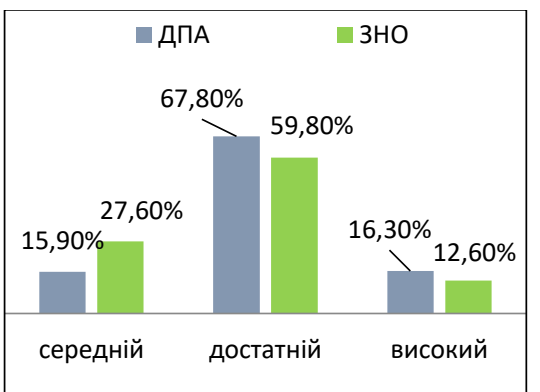

Рис. 1. Результати першого етапу дослідження

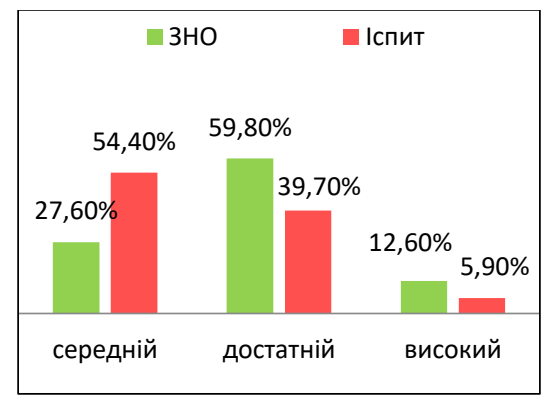

Рис. 2. Результати другого етапу дослідження

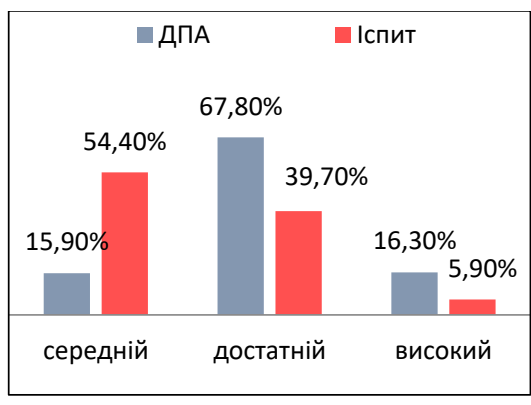

Рис. 3. Результати

третього етапу дослідження 
3 відповідних діаграм бачимо, що кількість респондентів достатнього і високого рівня зменшується за рахунок збільшення кількості респондентів середнього рівня (що «відчувають на собі» викладачі вищих навчальних закладів). Ці негативні зміни є статистично значущими.

Факторами впливу на результати 3НО, на нашу думку, є якість навчально-виховного процесу, а саме:

- мають місце ознаки необ'єктивного оцінювання навчальних досягнень учнів;

- тестові технології застосовуються вчителями переважно лише на уроках контролю знань та вмінь учнів;

- у більшості учнів відсутня система знань з окремих навчальних тем.

Щодо результатів іспиту з вищої математики студентів першого року навчання, можна зробити висновок, що студенти перших курсів погано адаптуються до нової системи навчання. Підґрунтям цьому $є$ те, що останній рік навчання в школі учні «спрямовані» на підготовку до зовнішнього незалежного оцінювання, а не на отримання системних знань чи підготовку до навчання у вищому навчальному закладі. Як результат більшість студентів перших курсів неспроможні якісно навчатися. На нашу думку, для уникнення такої ситуації, доцільно перший семестр присвятити шкільній математиці, узагальненню і систематизації основних фактів арифметики, геометрії, алгебри та початків аналізу. Необхідно переорієнтувати першокурсника з «відмітки» на «знання», на вміння вчитися.

\section{ВИСНОВКИ ТА ПЕРСПЕКТИВИ ДОСЛІДЖЕННЯ}

1. Проведений аналіз наукової, психолого-педагогічної, навчально-методичної літератури дозволяє трактувати моніторинг у широкому розумінні як систему збору, обробки, зберігання і розповсюдження інформації про стан освіти так і у вузькому - як супровідний контроль із поточним корегуванням педагогічної взаємодії суб'єкта та об'єкта у освітніх процесах.

2. Підтверджено, що система моніторингу має бути комплексною та проводитися на всіх рівнях управління освітою як запорука валідності, надійності, економічності, інтегрованості та практичності. Моніторинг навчальних досягнень студентів $є$ інструментом, який дозволяє забезпечити якісну математичну підготовку майбутніх фахівців.

3. Проведення експериментального дослідження дало змогу виявити відсутність узгодженості результату 3НО, шкільного середнього балу з математики та результатів іспиту з математики, що складали студенти першого року різних університетів.

4. Для уникнення прогалин та корекції знань першокурсників доцільно організувати протягом першого семестру повторювальний курс шкільної математики, завдання якого є узагальнення і систематизація основних фактів арифметики, геометрії, алгебри та початків аналізу. Це дозволить покращити якість математичної підготовки студентів закладів вищої освіти.

\section{Список використаних джерел}

1. Байназарова О.О., Ракчєєва В.В. Моніторинг та оцінювання якості освіти : [Методичний посібник]. Харків : ХНУ імені В. Н. Каразіна, 2009. 58 с.

2. Про освіту: Закон України від 05.09.2017 № 2145-VIII. URL: https://zakon.rada.gov.ua/laws/show/2145-19\#Text (дата звернення: 12.04.2021).

3. Національний звіт за результатами міжнародного дослідження якості освіти PISA-2018 / кол. авт. : М. Мазорчук (осн. автор), Т. Вакуленко, В. Терещенко, Г. Бичко, К. Шумова, С. Раков, В. Горох та ін. ; Український центр оцінювання якості освіти. Київ :УЦОЯО, 2019. 439 с. URL: https://testportal.gov.ua/wp-content/uploads/2019/12/PISA_2018_Report_UKR.pdf

4. Новиков Д. А. Статистические методы в педагогических исследованиях (типовые случаи). М. : М3-Пресс, 2004. 67с.

5. Організаційно-методичне забезпечення моніторингових досліджень якості загальної середньої освіти: монографія / О. І. Ляшенко, Т. О. Лукіна, Л. С. Ващенко, П. Б. Полянський, Ю. О. Жук ; за ред. О. І. Ляшенка. К. : Пед. думка, 2011. $160 \mathrm{c}$.

6. Офіційні звіти про проведення зовнішнього незалежного оцінювання результатів навчання, здобутих на основі повної загальної середньої освіти. URL: http://testportal.gov.ua/ofzvit/ (дата звернення: 17.03.2021).

7. Про оголошення 2020/2021 навчального року Роком математичної освіти в Україні: Указ президента України №31/2020. URL: https://www.president.gov.ua/documents/312020-32165 (дата звернення: 05.02.2021).

8. Якість освіти. URL : https://mon.gov.ua/ua/tag/yakist-osviti (дата звернення: 06.04.2021).

\section{References}

1. Bainazarova, O. O. \& Rakchieieva V. V. (2009) Monitorynh ta otsiniuvannia yakosti osvity [Monitoring and evaluation of education quality]. Kharkiv : KhNU imeni V. N. Karazina [in Ukraine].

2. Pro osvitu: Zakon Ukrainy [About education: Law of Ukraine] (n.d.). zakon.rada.gov.ua. Retrieved from https://zakon.rada.gov.ua/laws/show/2145-19\#Text [in Ukraine].

3. Mazorchuk, M. et al (2019). Natsionalnyi zvit za rezultatamy mizhnarodnoho doslidzhennia yakosti osvity PISA-2018 [National report on the results of the international survey on the quality of education PISA-2018]. Kyiv: UTSOYAO. Retrieved from https://testportal.gov.ua/wp-content/uploads/2019/12/PISA_2018_Report_UKR.pdf [in Ukraine].

4. Novykov, D.A. (2004). Statystycheskye metodu v pedahohycheskykh yssledovanyiakh (typovble sluchay) [Statistical Methods in Pedagogical Research (Typical Cases)]. M. : MZ-Press [in Russian].

5. Liashenko, O. I. (Ed.). (2011). Orhanizatsiino-metodychne zabezpechennia monitorynhovykh doslidzhen yakosti zahalnoi serednoi osvity [Organizational and methodological support of monitoring studies of the quality of general secondary education]. Kyiv : Ped. dumka [in Ukraine].

6. Ofitsiini zvity pro provedennia zovnishnoho nezalezhnoho otsiniuvannia rezultativ navchannia, zdobutykh na osnovi povnoi zahalnoi serednoi osvity [Official reports on conducting external independent evaluation of learning outcomes obtained on 
the basis of complete general secondary education] (n.d.). testportal.gov.ua. Retrieved from http://testportal.gov.ua/ofzvit/ [in Ukraine].

7. Pro oholoshennia 2020/2021 navchalnoho roku Rokom matematychnoi osvity v Ukraini: Ukaz prezydenta Ukrainy [On declaring the 2020/2021 academic year the Year of Mathematical Education in Ukraine: Decree of the President of Ukraine] (n.d.). president.gov.ua. Retrieved from https://www.president.gov.ua/documents/312020-32165 [in Ukraine].

8. Yakist osvity [Quality of education] (n.d.). mon.gov.ua. Retrieved from : https://mon.gov.ua/ua/tag/yakist-osviti [in Ukraine].

\section{KNOWLEDGE MONITORING AS A TOOL FOR PROVIDING QUALITY MATHEMATICAL TRAINING OF STUDENTS}

Anzhela Rozumenko

Communal institution of Sumy regional council

"Sumy Regional Gymnasium-Boarding School for Talented and Creatively Gifted Children", Ukraine

Anatolii Rozumenko

Sumy National Agrarian University, Ukraine

Abstract.

Problem formulation. The article describes the problem of reducing the quality of mathematical training of students of different specialties.

Materials and methods. During the preparation of the article the following research methods were used: comparative analysis of the theoretical provisions described in the scientific and educational literature; observation of mathematical training of future specialists in various fields; conversations with students; generalization of pedagogical experience in teaching mathematical disciplines, questionnaires (239 respondents) and statistical methods of experimental data processing (method of statistical hypotheses).

Results. Based on the analysis of monitoring research at different levels, it is concluded that the quality of mathematical training of future professionals has a tendency to decrease not depending on the training direction. The results of the experimental regional study, which confirm this conclusion, are presented.

The necessity of mathematical knowledge monitoring, as one of the tools to ensure higher level of mathematical training of students, is justified.

Methodical recommendations on improving the quality of mathematical preparation for the first-year students of different directions are offered.

Conclusions. It was confirmed that the monitoring system should be comprehensive and conducted at all levels of educational management as a guarantee of validity, reliability, economy, integration and practicality. Monitoring of students' academical achievements is a tool that allows to provide high quality mathematical training for future professionals. The implementation of the experimental study made possible to identify the lack of consistency between the results of the external evaluation, school average score in mathematics and results of the mathematics exam of first-year students of different universities. To avoid gaps and correct the knowledge of freshmen, it is advised to organize during the first semester a repetitive course of school mathematics, which task is to generalize and systematize the basic facts of arithmetic, geometry, algebra and the beginnings of analysis. This will improve the quality of mathematical training of students of higher education institutions.

Key words: mathematical training, monitoring, student, quality of education.

\section{(cc) BY-NC-SA}

This work is licensed under Creative Commons Attribution-NonCommercial-ShareAlike 4.0 International License. 